\title{
Erratum to: Risk Factors for the Development of Psychopathology Following Trauma
}

Sehrish Sayed $^{1} \cdot$ Brian M. Iacoviello $^{1} \cdot$ Dennis S. Charney $^{1}$

Published online: 26 August 2015

(C) Springer Science+Business Media New York 2015

Erratum to: Curr Psychiatry Rep (2015) 17:70

DOI 10.1007/s11920-015-0612-y

The original version of this article mistakenly duplicated reference 45 in the reference list, thus references $46-84$ are misnumbered as $45-83$.

The online version of the original article can be found at http://dx.doi.org/ 10.1007/s11920-015-0612-y.

$\triangle$ Sehrish Sayed

seharish.moughal@mssm.edu

1 Department of Psychiatry, Icahn School of Medicine at Mount Sinai, One Gustave L Levy Pl, Box 1230, New York, NY 10029, USA 